\title{
Isolation of a clonal lineage of IgA broadly neutralizing antibodies from a chronically infected Tanzanian subject
}

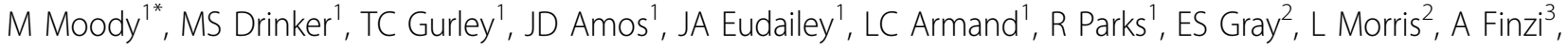 \\ X Yang ${ }^{3}$, J Sodroski ${ }^{3}$, H Liao ${ }^{1}$, GD Tomaras', DC Montefiori', BF Haynes ${ }^{1}$
}

From AIDS Vaccine 2012

Boston, MA, USA. 9-12 September 2012

\section{Background}

Only $\sim 20 \%$ of HIV-1-infected subjects develop broadly neutralizing antibodies (bnAbs) and the origins of such antibodies remains obscure. To date, all isolated bnAbs have been of the IgG isotype.

\section{Methods}

Memory B cells from a chronically infected Tanzanian subject with plasma broad neutralizing activity were labeled with a consensus $C$ envelope (Env) and Env+ cells sorted as single cells. Immunoglobulin heavy and light chain genes were amplified by PCR and analyzed for gene usage and isotype, and then were expressed as recombinant monoclonal antibodies (mAbs). MAbs were assayed for binding to Env proteins and for neutralization of multiple HIV-1 strains.

\section{Results}

We isolated $13 \mathrm{mAbs}$ that bound Env proteins; of these, 11 were members of three clonal lineages, each of which spanned two time points. Six mAbs in one lineage were all IgG1, used $\mathrm{V}_{\mathrm{H}} 1 \sim 69$, had an average mutation frequency of $12 \%$, mapped to the CD4 contact region, and had modest neutralization activity. In contrast, three mAbs in a second lineage had two members that were IgA2, used $\mathrm{V}$ $\mathrm{H}^{3} \sim 66$, had an average mutation frequency of $16 \%$, and neutralized 11/27 (41\%) of tier 2 pseudoviruses tested.

\section{Conclusion}

We have isolated the first natural IgA mAbs with broad neutralizing activity. These data demonstrate that class

${ }^{1}$ Duke University Medical Center, Durham, NC, USA

Full list of author information is available at the end of the article switching to IgA can occur in the generation of bnAbs, an event that is essential for the generation of neutralizing IgA antibodies at mucosal surfaces.

\section{Author details}

'Duke University Medical Center, Durham, NC, USA. ${ }^{2}$ National Institute for Communicable Disease, Johannesburg, South Africa. ${ }^{3}$ Dana-Farber Cancer Institute, Boston, MA, USA.

Published: 13 September 2012

doi:10.1186/1742-4690-9-S2-035

Cite this article as: Moody et al: Isolation of a clonal lineage of IgA broadly neutralizing antibodies from a chronically infected Tanzanian subject. Retrovirology 2012 9(Suppl 2):O35.
Submit your next manuscript to BioMed Central and take full advantage of:

- Convenient online submission

- Thorough peer review

- No space constraints or color figure charges

- Immediate publication on acceptance

- Inclusion in PubMed, CAS, Scopus and Google Scholar

- Research which is freely available for redistribution
() Biomed Central 